\title{
B6 - Determinação dos aminoácidos alanina, glicina e ácido glutâmico na eritropoetina humana recombinante (epohr) for- mulado sem albumina soro humana por clae-uv
}

Melissa Chamon Alves ${ }^{1}$; Eduardo da Silva Gomes de Castro ${ }^{1}$; Annibal Duarte Pereira Netto ${ }^{1}$.

\section{1 - Bio-Manguinhos/FIOCRUZ}

\section{Introdução}

A Eritropoetina Humana Recombinante (EPOhr) produto biológico utilizado no tratamento de anemias severas, tem sido produzida utilizando-se a tecnologia de DNA recombinante e preparações farmacêuticas da EPOhr estão sendo mundialmente fornecidas por diversos fabricantes4. Algumas destas preparações farmacêuticas utilizam grandes quantidades de albumina de soro humano (HSA) como excipiente cuja finalidade é evitar a adsorção da proteína nas paredes de vidro dos frascos, além de aumentar sua estabilidade durante o armazenamento5. Um inconveniente à utilização de HSA é o fato desta proteína ser extraída do sangue humano e, por esta razão, requerer cuidadoso controle a fim de se prevenir a disseminação de doenças importantes.

Como alternativa à utilização da HSA, a formulação em questão utiliza três aminoácidos, alanina, glicina e ácido glutâmico, sendo necessário o desenvolvimento de uma metodologia para a determinação dos aminoácidos presentes.

\section{Objetivos}

Determinação dos aminoácidos alanina, glicina e ácido glutâmico no produto final Alfaepoetina sem albumina de soro humano por cromatografia a líquido de alta eficiência.

\section{Metodologia}

Durante o desenvolvimento da metodologia, utilizou-se amostras de diferentes lotes experimentais de eritropoietina sem albumina humana nas 3 apresentações 2000, 4000 e 10000 UI, além de padrões USP de alanina, glicina e ácido glutâmico para a construção da curva analítica. O equipamento utilizado foi um Cromatógrafo a Líquido de Alta Eficiência (Waters, Alliance), equipado com um detector de UV, modelo 2996. Empregou-se coluna analítica do tipo C18, marca J.T. Baker, 4,6 x 100nm, 5 mm. Fase móvel “A”: Ácido Triflu- 
oracético 0,1\% em água Milli-Q e fase móvel "B”: Ácido Trifluoracético 0,1\% em Acetonitrila, modo gradiente, vazão $1,5 \mathrm{~mL} / \mathrm{min}$. Para a derivatização das amostras e padrões utlizou-se o 1-flúor-2-4-dinitrobenzeno, também conhecido como reagente de Sanger, marca Sigma, lote BCBK7708V.

Inicialmente realizou-se a reação de derivatização pré-coluna da mistura de aminoácidos com o reagente de Sanger (2,4-dinitro-1-flúor-benzeno ou FDNB) em meio tamponado, utilizando solvente adequado, à temperatura controlada e ao abrigo da luminosidade por tempo determinado, para a adição de um grupamento, o 2,4-dinitrofenil, que absorve radiação eletromagnética na faixa do ultravioleta ( 190 - $400 \mathrm{~nm}$ ) e consequente formação de um derivatizado estável e detectável. Posteriormente realizou-se a separação por cromatografia líquida de alta eficiência de fase reversa. Determinou-se a concentração de cada aminoácido através da preparação de uma curva analítica.

\section{Resultados}

A metodologia proposta apresentou boa resolução cromatográfica entre os picos dos aminoácidos e mostrou-se linear na faixa de 0,5 a $1,5 \mathrm{mg} / \mathrm{mL}$ para alanina e 1,0 a 3,0 mg/mL para glicina e ácido glutâmico, com coeficientes de correlação iguais ou maiores que 0,99 para os três aminoácidos.

\section{Conclusão}

O método mostrou-se adequado para a determinação das substâncias de interesse e poderá ser utilizado na rotina de controle de qualidade de Bio-Manguinhos.

Palavras-Chave: Eritropoetina, Aminoácidos, Cromatografia 